\title{
Budżet obywatelski jako usankcjonowana szczególna forma konsultacji społecznych - analiza administracyjnoprawna
}

\begin{abstract}
\# budżet obywatelski \# budżet partycypacyjny \# konsultacje społeczne \# miasto na prawach powiatu \# aspekty administracyjnoprawne \# miasta na prawach powiatu \# konsultowanie \# demokracja bezpośrednia \# instytucja demokracji bezpośredniej.

\# civic budget \# participatory budget \# social consultations \# county capital \# consultations \# direct democracy \# institution of direct democracy.
\end{abstract}

Artykuł poświęcony jest analizie formy prawnej instytucji budżetu obywatelskiego. Podjęta zostanie też próba identyfikacji najważniejszych wyzwań stojących przed jednostkami samorządu terytorialnego z administracyjnoprawnego punktu widzenia w zakresie wprowadzania budżetu obywatelskiego.

Budżet obywatelski to zarówno szczytna idea, jak i instytucja. Jeżeli jednak jego podstawy prawne nie zostaną właściwie wskazane, to nie będzie mógł prawidłowo funkcjonować. To jednostki samorządu terytorialnego odpowiadają za poprawność aktu stanowiącego podstawę działania budżetu obywatelskiego, należy więc zwrócić uwagę na to, czy jest to akt prawa miejscowego. Przedmiotem rozważań uczyniono także kształtowanie zakresu podmiotowego głosujących.

The article is about the legal aspects of the civic budget. In addition, I wrote about the challenges for municipalities connected with the civic budget. A citizen's budget should be carried out. A civic budget works properly if it is based on the relevant local law. Municipalities must remember to enact the right act and correctly determine who can vote.

\section{OPEN ACCESS}

Citation: Maciąg A., Budżet obywatelski jako usankcjonowana szczególna forma konsultacji społecznych - analiza administracyjnoprawna, "Miasto. Pamięć i Przyszłość", 3/2 (2018).

https://doi.org/10.26774/mpp.83

Editor: Jerzy Korczak

Received: October, 2018

Accepted: December, 2018

Published: December, 2018

Copyright: @ Ośrodek „Pamięći Przyszłość" This is an open access article distributed under the terms of the Creative Commons Attribution-ShareAlike Licence, which permits unrestricted use, distribution, and reproduction in any medium, provided the original author and source are credited, with indications if any changes are made. All derivative works must be licensed under the same licence. 
mgr Anna Maciąg - doktorantka w Zakładzie Prawa Administracyjnego Instytutu Nauk Administracyjnych na Wydziale Prawa, Administracji i Ekonomii Uniwersytetu Wrocławskiego 


\section{Z historii budżetu obywatelskiego}

Idea budżetu obywatelskiego, na której opiera się współcześnie instytucja budżetu obywatelskiego, narodziła się w ostatnim dwudziestoleciu XX wieku, a miastem-pionierem było brazylijskie Porto Alegre, w którym organy oddały społeczności lokalnej prawo do współudziału w kształtowaniu finansów budżetu lokalnego².

Z czasem wzorce z Ameryki Południowej zaczęto przenosić do „krajów europejskich (Hiszpanii, Belgii, Włoszech, Niemczech, Francji, Portugalii, Danii, Szwajcarii, Holandii, Wielkiej Brytanii, Polski), afrykańskich (Kamerun), a nawet azjatyckich (Sri Lanca)"3. Nie było to jednak odtwórcze wykorzystywanie wzorca, prawodawstwo krajowe oraz wieloletnie tradycje i przyzwyczajenia mieszkańców wpływały bowiem na konieczność dostosowywania instytucji do realiów danego państwa bądź jego części (jednostki samorządu terytorialnego, miejscowości). Adaptacja tej instytucji w Polsce ograniczyła się do wyodrębnienia przez

Miasto. Pamięć i Przyszłość 3/2 (2018) ISSN 2543-621X organy jednostek samorządu terytorialnego części budżetu, którą gospodarują mieszkańcy5.

W 2011 r, w Polsce, po raz pierwszy instytucję budżetu obywatelskiego wykorzystało miasto Sopot, z inicjatywy Sopockiej Inicjatywy Rozwojowej $(\mathrm{SIR})^{6}$. Budowanie rodzimego budżetu obywatelskiego okazało się jednak zadaniem wywołującym liczne spory, wątpliwości i obawy. Pierwotnie proponowano, by rozdysponować 1 proc. wydatków, czyli ok. 2 ml zł, a formę budżetu wypracować przy

1. Miasto to liczyło ok. 1,5 miliona mieszkańców, obejmując aglomerację zamieszkiwaną przez prawie 4,5 miliona osób. Zob. M. Baraniecki, O swoich pieniaqdzach decydujemy sami - planowanie partycypacyjne budżetu gminy, [w:] Partycypacja społeczna w samorządzie terytorialnym, red. B. Dolnicki, Warszawa 2014, s. 570-582. Porto Alegre to ważny port rzeczny, ośrodek akademicki oraz miejscowości o dużym bezrobociu i problemach mieszkaniowych. Więcej na ten temat: A. Krzewińska, Historia budżetu obywatelskiego, "Kronika Miasta Łodzi” 2013, nr 3, s. 21.

2. W Polsce takie rozwiązanie byłoby niedopuszczalne z uwagi na przepisy dotyczące finansów publicznych. Zob. E. T. Szuber-Bednarz, Budżet partycypacyjny w wybranych jednostkach samorzadu terytorialnego w Polsce, [w:] Jawność w samorządzie terytorialnym, red. B. Dolnicki, Warszawa 2015, s. 729-736.

3. A. Krzewińska, dz. cyt., s. 20.

4. Ograniczenie to należy postrzegać w porównaniu do charakteru budżetu obywatelskiego w Porto Alegre. W kontekście rodzimych tradycji jest to duży krok w stronę społeczności lokalnych współuczestniczących, w ramach instytucji demokracji bezpośredniej.

5. E.T. Szuber-Bednarz, dz. cyt.

6. A. Krzewińska, dz. cyt., s. 22 i nast. 
udziale mieszkańców i radnych, organizując kampanię informacyjno-edukacyjną. W maju 2011 r. przeznaczono na budżet obywatelski $3 \mathrm{mln}$ zł oraz powołano doraźną Komisję ds. budżetu obywatelskiego, której zadaniem było ustalenie szczegółów projektu. Informowanie mieszkańców o inicjatywie odbyło się za pośrednictwem strony internetowej urzędu miasta, rozwieszanych plakatów, ogłoszeń publikowanych w lokalnej gazecie oraz druków rozsyłanych do poszczególnych mieszkańców. W ciągu półtora miesiąca zebrano ponad 500 propozycji oraz uwag do samego budżetu, które poddano weryfikacji przez pracowników urzędu.

7. W 2011 r. - Gdańsk, w 2012 r. dołączyły: Bydgoszcz, Elbląg, Gorzów Wielkopolski, Płock, Poznań, Wałbrzych, Włocławek, Tarnów, Toruń, Zielona Góra. Zob. Budżety partycypacyjne. Mapa, http:// bp.partycypacjaobywatelska.pl/mapa/ [dostęp: 10.07.2018].

8. W 2011 r. - gmina Karpacz, w 2012 r. dołączyły gminy: Kędzierzyn Koźle, Milicz, Wieruszów. Zob.] Budżety partycypacyjne...

9. Np. powiat wałbrzyski. Zob. Wyniki Budżetu Partycypacyjnego 2017, http://www.powiat.walbrzych.pl/organizacje-pozarzadowe/ bud\%C5\%BCet-partycypacyjny-2017.html [dostęp: 10.07.2018].

10. Np. Województwo Małopolskie. Zob. Budżet obywatelski województwa małopolskiego, (http://www.bo.malopolska.pl/) [dostęp na dzień: 17.05.2018]. Innym przykładem jest Województwo Łódzkie. Zob. Pierwszy wojewódzki budżet obywatelski, http://lodzkie.pl/strona-glowna/aktualnosci/pierwszy-wojew\%C3\%B3dzki-bud\%C5\%BCet-obywatelski [dostęp: 10.07.2018].

11. Por. Internacjonalizacja administracji publicznej, red. Z. Czarnik Zbigniew, J. Posłuszny, L. Żukowski, Warszawa 2015; K. Kępka, J. Marczak, Budżet partycypacyjny w Polsce na przykładzie budżetu obywatelskiego miasta Łodzi. Analiza finansowa, "Finanse Komunalne" 2016, nr 1-2; R. Marchaj, Charakter prawny uchwały rady gminy w sprawie budżetu obywatelskiego, „Samorząd Terytorialny” 2017, nr 11; R. Marchaj, Samorząowe konsultacje społeczne, Warszawa 2016.

12. D. J. Kościuk i inni, Podstawy prawne dotyczace budżetu partycypacyjnego, [w:] Sposoby realizacji zadań publicznych, red. B. Dolnicki, Warszawa 2017.

13. Por. Zasady WBO 2017, (http://www.wroclaw.pl/rozmawia/zasady-wbo-2017) [dostęp: 10.07.2018] oraz Budżet partycypacyjny, http://m.mc.gov.pl/budzet-partycypacyjny [dostęp: 10.07.2018].

14. Ustawa z dnia 11 stycznia 2018 r. o zmianie niektórych ustaw w celu zwiększenia udziału obywateli w procesie wybierania, funkcjonowania i kontrolowania niektórych organów publicznych (Dz. U., poz. 130).
Nie obyło się bez „wpadek” - część projektów odrzucono, ponieważ urzędnicy nie potrafili ich wycenić, bądź arbitralnie uznali za niekorzystane dla miasta. Ponadto, wybrane przez mieszkańców (w głosowaniu osobistym i elektronicznym) projekty, prezydent miasta próbował uzupełnić o kilka własnych. Ostatecznie mieszkańców poinformowano o propozycjach, które zdobyły najwięcej głosów (przy 7 proc. frekwencji) oraz o dwóch, które wybrał do realizacji dodatkowo prezydent miasta.

Z czasem kolejne miasta7, gminy', a nawet powiaty9 i województwa10 ${ }^{10}$ decydowały się na próby wprowadzenia budżetu obywatelskiego.

Pozostała jednak wątpliwość w zakresie podstaw prawnych realizowania instytucji budżetu obywatelskiego. W wielu definicjach budżetu obywatelskiego klasyfikowano go jako formę konsultacji społecznych ${ }^{11}$. W literaturze naukowej zdarzają się i głosy odmienne, uznające, iż budżet obywatelski jest instytucją odrębną od konsultacji społecznych, a jedynie z braku samodzielnej procedury opiera się na regulacjach dotyczących konsultacji społecznych². Można także spotkać się z tezą, iż podstawą budżetu obywatelskiego jest umowa społeczna pomiędzy mieszkańcami i organami jednostek samorządu terytorialnego ${ }^{13}$. Stan niepewności prawnej w tym zakresie trwał aż do 31 stycznia 2018 r.

\section{Charakterystyka instytucji budżetu obywatelskiego}

Nowela ustaw ustrojowych w art. $1^{14}$ usankcjonowała instytucję budżetu obywatelskiego, Miasto. Pamięć i Przyszłość 3/2 (2018) ISSN 2543-621X 
traktując ją jako szczególną formę konsultacji społecznych ${ }^{15}$. Nowela weszła w życie 31 stycznia 2018 r., aczkolwiek na mocy jej art. 15, przepisy dotyczące budżetu obywatelskiego stosuje się od kadencji organów jednostek samorządu terytorialnego następujących po kadencji, w czasie której nowela weszła w życie, a więc od kadencji rozpoczynającej się jesienią 2018 r.

Normatywna regulacja objęła następujące aspekty:

1) obligatoryjność przeprowadzenia budżetu obywatelskiego w miastach na prawach powiatu;

2) zakres podmiotowy, ustalając, iż będą to mieszkańcy ${ }^{16}$;

3) zakres przedmiotowy, wskazując, że będzie to głosowanie corocznie o części wydatków budżetu gminy;

4) skutek w formie uwzględnienia wybranych zadań w uchwale budżetowej jednostki samorządu terytorialnego, przy czym w toku prac nad projektem uchwały budżetowej nie może usuwać lub zmieniać w stopniu istotnym zadań wybranych w ramach budżetu obywatelskiego;

5) określenie w uchwale organu stanowiącego i kontrolnego danej jednostki samorządu terytorialnego wymagań, jakie powinien spełnić projekt budżetu obywatelskiego (przy wskazaniu nieenumeratywnego katalogu elementów uchwały).

Z kolei swobodę decyzyjną pozostawiono organom jednostek samorządu terytorialnego w zakresie:

Miasto. Pamięć i Przyszłość 3/2 (2018) ISSN 2543-621X
1) przeprowadzania budżetu obywatelskiego w województwach, powiatach i gminach, niebędących miastem na prawach powiatu;

2) wysokości środków poddanych pod głosowanie, aczkolwiek w miastach na prawach powiatu wysokość budżetu obywatelskiego wynosi co najmniej 0,5 proc. wydatków gminy zawartych w ostatnim przedłożonym sprawozdaniu z wykonania budżetu;

3) wyboru czy środki wydatkowane w ramach budżetu obywatelskiego będą dzielone na pule obejmujące całość gminy i jej części w postaci jednostek pomocniczych lub grup jednostek pomocniczych (dotyczy wyłącznie gmin).

W konsekwencji na gruncie samorządowych ustaw ustrojowych zdecydowano się na

15. Por. art. 5a ust. 3-7 ustawy z dnia 8 marca 1990 r. o samorządzie gminnym (Dz. U. z 2018 r., poz. 994, z późn. zm.); art. 3d ust. 3-6 ustawy z dnia 5 czerwca 1998 r. o samorządzie powiatowym (Dz. U. z 2018 r., poz. 995, z późn. zm.) oraz art. 10a ust. 3-6 ustawy z dnia 5 czerwca 1998 r. o samorządzie województwa (Dz. U. z 2018 r., poz. 913, z późn. zm.).

16. Pojęcie mieszkańca definiuje się (z uwagi na brak stosownej regulacji) w oparciu o przepisy regulacji cywilnych. Faktu zamieszkania nie należy mylić z zameldowaniem wynikającym z obowiązku meldunkowego ustanowionego art. 24 ustawy z dnia 24 września 2010 r. o ewidencji ludności (Dz. U. z 2017 r., poz. 657, z późn. zm.).

O definicji miejsca zamieszkania orzekał także Naczelny Sąd Administracyjny, uznając (analogicznie jak sądy powszechne), iż składa się ona z dwóch powiązanych ze sobą elementów, tj. obiektywnego (pobycie stałym w jednej miejscowości - corpus) oraz subiektywnego (przejawiającego się w postaci uzewnętrznionego zamiaru, woli pobytu - animus) - wyrok NSA z dnia 8 maja 2013 r., II FSK 1831/11 (LEX nr 521414811). Przy czym wyrażenie zamiaru stałego pobytu nie jest czynnością prawną i nie wymaga złożenia oświadczenia woli - zob. postanowienie NSA z dnia 24 lipca 2012 r., I OW 89/12 (LEX nr 521428302).

Mieszkańcem może być wyłącznie osoba fizyczna (odmienne stanowisko prezentował Antoni Agopszowicz, uznając pominięcie statusu osób prawnych w kontekście konsultacji społecznych za niedopatrzenie ustawodawcy, zob. A. Agopszowicz, Art. 4, [w:] Ustawa o samorzadzie terytorialnym. Komentarz, red. A. Agopszowicz, Warszawa 1999, s. 44), bez względu na: wiek, poczytalność, zdolność do czynności prawnej, posiadanie praw publicznych, obywatelstwo, zameldowanie. 
unormowanie faktycznie działającej, ale jeszcze nie dawno nie w pełni usankcjonowanej, instytucji demokracji bezpośredniej.

Należy zauważyć, że chociaż projekty, które zwyciężą, należy umieścić w uchwale organu stanowiącego i kontrolującego danej jednostki samorządu terytorialnego, to jednak nie zagwarantowano środka prawnego, który nakaże organom jednostki samorządu terytorialnego, projekt zrealizować (czy zrealizować dokładnie w kształcie wskazanym w projekcie). Owszem, będą istnieć pewne środki reakcji, jak brak absolutorium dla organu wykonawczego czy referendum odwoławcze. Niemniej projekt może wciąż być niezrealizowany. W instytucji pokłada się wiarę w dotrzymywanie obietnic przez piastunów/członków organów jednostek samorządu terytorialnego.

Uwagę zwraca jednakże istniejąca nierówność pomiędzy stosowaniem instytucji w gminach będących miastami na prawach powiatu a województwami, powiatami i gminami niebędącymi miastem na prawach powiatu. Tylko u tych pierwszych budżet obywatelski musi zostać wdrożony i to przy przeznaczeniu na niego przynajmniej określonej puli środków.

\section{Wyzwania w stosowaniu budżetu obywatelskiego}

Jak sygnalizowano już wcześniej, instytucja budżetu obywatelskiego dotychczas realizowana była na różne sposoby i w oparciu o różne podstawy normatywne. Na podstawie dotychczasowego dorobku naukowego i orzeczniczego w zakresie wykorzystywania instytucji konsultacji społecznych, jak i budżetu obywatelskiego, wskazać można na dwa wybrane zagadnienia, istotne z punktu widzenia wykorzystywania tej instytucji demokracji bezpośredniej.

\subsection{Publikowanie uchwały}

\section{w wojewódzkim dzienniku urzędowym}

Uchwała regulująca zasady i tryb zgłaszania projektów czy sposób przeprowadzenia głosowania, zasadniczo jest aktem prawa miejscowego ${ }^{17}$. Skorelowany z tym jest obowiązek opublikowania przedmiotowej uchwały w wojewódzkim dzienniku urzędowym. Na zasadach ogólnych uchwała podlega przesłaniu jej do wojewody celem umożliwienia przeprowadzenia badania nadzorczego. Wyzwaniem staje się więc zadbanie o terminowość podjęcia uchwały, by - nawet uwzględniając skutki postępowania nadzorczego (np. stwierdzenie jej nieważności w całości lub części) - mogła zostać opublikowana i wejść w życie przed rozpoczęciem biegu terminów, które wskazuje.

\subsection{Ustalenie zakresu podmiotowego}

Przepisy samorządowych ustaw ustrojowych, jednoznacznie wskazują, iż uprawnionymi do głosowania są mieszkańcy. Dotychczasowe doświadczenia z konsultacjami społecznymi wskazują, iż mimo spójności doktryny i judykatura w zakresie definiowania pojęcia mieszkańca, organy jednostek samorządu terytorialnego usilnie decydują się na modyfikowanie zakresu podmiotowego. Brak 
jest podstaw normatywnych do ingerowania w zakres podmiotowy budżetu obywatelskiego, czy to konsultacji społecznych ${ }^{18}$, w szczególności, kiedy próbuje się ograniczać wiek osób uprawnionych ${ }^{19}$, żądać posiadania numeru PESEL ${ }^{20}$ czy udowadniania faktu zameldowania na terenie danej jednostki samorządu terytorialnego ${ }^{21}$.

Na marginesie dodać należy, że niefortunna jest nazwa instytucji. Wyróżnik „obywatelski" może powodować błędne myślenie, że chodzi o mieszkańców-obywateli. Wybór formy „budżet partycypacyjny" nie powodowałby takich wątpliwości, jednak nazwa ta jest mniej rozpowszechniona.

Wyzwaniem dla jednostek samorządu terytorialnego jest więc zwrócenie uwagi na to, by nie ingerować w jasno i precyzyjnie określony ustawowo zakres podmiotowy. Odmienne stanowisko może wpłynąć na wydłużenie terminu od procedowania nad uchwałą do jej wejścia w życie, przez co może się okazać, iż nie uda się zrealizować budżetu obywatelskiego (istotne jest to przede wszystkim dla miast na prawach powiatu).

\section{Zakończenie}

Usankcjonowanie instytucji budżetu obywatelskiego było ważnym zadaniem. Kreacja Miasto. Pamięć i Przyszłość 3/2 (2018) ISSN 2543-621X nowej instytucji demokracji bezpośredniej mogła przebiec wieloma drogami. Wybrano tę, którą podnoszono w doktrynie najczęściej. Nie została ona jeszcze skutecznie wdrożona, więc trudno oceniać jej efektywność. Niemniej już na tym etapie widać wyzwania, jakie stoją przed jednostkami samorządu terytorialnego. Po raz pierwszy korzystać będą one z instytucji na ujednoliconych zasadach, w których nie ma już aż tak wiele płaszczyzny na swobodę i prawotwórstwo.

W mojej ocenie, najważniejsze z punktu widzenia mieszkańców będzie to, by uregulować podstawy funkcjonowania budżetu obywatelskiego we właściwym akcie prawa lokalnego. Jeżeli uchwała będzie stanowiła akt prawa miejscowego, to koniecznie należy ją ogłosić w wojewódzkim dzienniku urzędowym, i w szczególności uważać, aby w jej treści nie ingerować w zakres podmiotowy uczestników głosowania. Dzięki temu zyska się czas na dostosowanie technologii, by instytucję wdrożyć. W przeciwnym wypadku może się okazać, że uchwałę trzeba będzie podjąć ponownie bądź zmienić, co wydłuży czas procesowania, a więc i rozpoczęcia działania instytucji.

18. Por. wyrok WSA w Opolu z dnia 17 kwietnia 2018 r., II SA/Op 64/18 (LEX nr 2483810); wyrok WSA w Kielcach z dnia 13 kwietnia 2017 r., II SA/Ke 38/17 (LEX nr 2289689).

19. Wyrok WSA w Poznaniu z dnia 18 kwietnia 2018 r., IV SA/Po 176/18 (LEX nr 2497094).

20. Wyrok WSA w Gliwicach z dnia 29 marca 2017 r., II SA/G 106/17 (LEX nr 2284637).

21. Wyrok WSA w Gliwicach z dnia 14 stycznia 2014 r., I SA/GI 1291/13 (LEX nr 1529502). 


\section{Literatura}

- M. Banat, Konsultacje społeczne w samorzadzie terytorialnym, "Samorząd Terytorialny” 2014, nr 1-2.

- M. Bożek, Konstytucyjne podstawy partycypacji spotecznej i formy jej realizacji w samorządzie terytorialnym, „Przegląd Sejmowy” 2012, nr 5.

- P. Glejt, D. Tykwińska-Rutkowska, Prawna regulacja budżetu obywatelskiego a jego praktyczna realizacja - czyli o uspołecznianiu wykonywania zadań publicznych na przykładzie rozwiqzań przyjętych w Trójmieście, „Gdańskie Studia Prawnicze” 2015, nr 2.

- Internacjonalizacja administracji publicznej, red. Z. Czarnik, J. Posłuszny, L. Żukowski, Warszawa 2015.

- Jawność w samorzadzie terytorialnym, red. B. Dolnicki, Warszawa 2015.

- K. Kępka, J. Marczak, Budżet partycypacyjny w Polsce na przykładzie budżetu obywatelskiego miasta Łodzi. Analiza finansowa, „Finanse Komunalne" 2016, nr $1-2$.

- J. Korczak, P. Lisowski, A. Ostapski, Ustrój samorzadu terytorialnego. Materiały dydaktyczne, Wrocław 2017.

- K. Kozłowski, Gminne konsultacje społeczne - analiza konstytucyjnoprawna, "Samorząd Terytorialny” 2018, nr 1-2.

- A. Krzewińska, Historia budżetu obywatelskiego, „Kronika Miasta Łodzi” 2013, nr 3.

- R. Marchaj, Charakter prawny uchwaty rady gminy w sprawie budżetu obywatelskiego, "Samorząd Terytorialny" 2017, nr 11.
- R. Marchaj, Samorzadowe konsultacje społeczne, Warszawa 2016.

- Partycypacja spoteczna w samorzadzie terytorialnym, red. B. Dolnicki, Warszawa 2014.

- M. Radziszewski, Wybrane instrumenty wykorzystywane w procesie budowy społeczeństwa obywatelskiego, "Samorząd Terytorialny” 2016, nr 6.

- Sposoby realizacji zadań publicznych, red. B. Dolnicki, Warszawa 2017.

- Ustawa o samorzadzie terytorialnym. Komentarz, red. A. Agopszowicz, Warszawa 1999.

- Ustawa o samorzadzie gminnym. Komentarz, red. B. Dolnicki, Warszawa 2018.

\section{Źródła internetowe}

- Budżet obywatelski województwa małopolskiego http://www.bo.malopolska.pl/.

- Budżet partycypacyjny http://m.mc.gov.pl/ budzet-partycypacyjny.

- Budżety partycypacyjne. Mapa, http://bp.partycypacjaobywatelska.pl/mapa/.

- Pierwszy wojewódzki budżet obywatelski, http:// lodzkie.pl/strona-glowna/aktualnosci/pierwszy-wojew\%C3\%B3dzki-bud\%C5\%BCet-obywatelski.

- Wyniki Budżetu Partycypacyjnego 2017, http://www. powiat.walbrzych.pl/organizacje-pozarzadowe/ bud\%C5\%BCet-partycypacyjny-2017.html.

- Zasady WBO 2017, http://www.wroclaw.pl/ rozmawia/zasady-wbo-2017. 